\title{
Kualitas Indeks Track Geometri Sebagai Indikator Penilaian Kualitas Track Melalui Metode Yang Berbeda (Studi Kasus: Cirebon-Cikampek)
}

\author{
Dyni Indar Karunianingrum dan Hera Widyastuti
}

Departemen Teknik Sipil, Institut Teknologi Sepuluh Nopember, Surabaya

Corresponding Author: hera.widyastuti@yahoo.co.uk

\section{ARTIKEL INFO}

\section{Informasi Artikel}

Artikel masuk: 22-7-19

Artikel revisi: -

Artikel diterima: 26-12-19

\begin{abstract}
ABSTRAK
Untuk mengatasi pergerakan pertumbuhan lalu lintas jaringan kereta api di Indonesia, khususnya di Jalur Cirebon-Cikampek dimana rute tersebut merupakan rute tersibuk di utara Pulau Jawa, hal itu dapat mempengaruhi kondisi geometri lintasan. Beberapa parameter geometri yang berpengaruh diantaranya adalah angkatan, listringan, lebar spur, dan pertinggian. Perlu adamya suatu pemeliharaan untuk mengukur suatu kondisi dan kualitas lintasan dengan menggunakan kereta ukur EM-120. Dibutuhkan pemeliharaan untuk mengukur kondisi dan kualitas lintasan menggunakan kereta ukur EM-120. Hasil kereta ukur menunjukkan nilai standar deviasi dari setiap parameter sehingga hasil kualitas segmen secara keseluruhan disebut Indeks Kualitas Track (TQI). Penelitian ini dilakukan untuk menganalisis Indeks Kualitas Track berdasarkan Standar Kereta Api Indonesia, Polandia Koefisien J-Sintetis dan Perkeretaapian India. Untuk mengetahui perbedaan hasil analisa indeks kualitas lintasan, digunakan metode tabulasi silang dan regresi linier berganda. Hasil yang didapatkan dari tabulasi silang yaitu selisih perbedaan pengukuran secara statistik sedangkan regresi linier berganda untuk mengetahui seberapa besar parameter yang mempengaruhi nilai kualitas lintasan.
\end{abstract}

\section{PENDAHULUAN}

Kereta api merupakan alat transportasi massal yang umumnya terdiri dari lokomotif (kendaraan dengan tenaga gerak yang berjalan sendiri) dan rangkaian kereta atau gerbong yang bergerak di atas rel. Sebagai alat transportasi massal kereta api adalah angkutan yang efisien untuk jumlah penumpang yang tinggi sehingga sangat cocok diterapkan pada koridor suatu wilayah yang padat. Pulau Jawa merupakan salah satu Pulau dengan jaringan konektivitas perkeretapian terbesar di Indonesia dalam fungsi operasionalnya salah satunya yaitu jalur kereta api Cirebon-Cikampek.

Peranan jalur kereta api adalah untuk memandu pergerakan atau perjalanan lokomotif, menanggung efek komprehensif dari kontribusi variabel lingkungan dan beban dari roda, mendistribusikan beban roda ke jalan, jembatan atau terowongan, menyediakan lintasan yang mulus untuk menjalankan roda, menjaga biaya operasi, keamanan perjalanan dan kenyamanan penumpang dalam kisaran yang diterima dan bantalan dalam kondisi baik [1]. Terkait dengan hal ini, kecelakaan lalu lintas kereta api telah lama menjadi masalah sosial-ekonomi yang telah menyebabkan meningkatnya kekhawatiran masyarakat di seluruh dunia [2]. Perawatan rel kereta api mahal dan sulit untuk dikelola secara efektif [3]. Hal ini disebabkan oleh fakta bahwa ada sejumlah parameter yang mempengaruhi turunnya penurunan kualitas lintasan. Dalam mengukur kondisi lintasan, biasanya hanya mempertimbangkan salah satu dari banyak aspek dan parameter yang dapat menyebabkan suatu penurunan kualitas lintasan. Angka-angka yang dihasilkan dari parameter terkait secara objektif sehingga disimpulkan untuk memberikan ukuran kualitas segmen secara keseluruhan yang biasa disebut Track Quality Index (TQI). Penggunaan TQI memberikan kemungkinan untuk menilai indikator kinerja jalur kereta api, untuk merancang intervensi, dan untuk membandingkan kinerja lintasan sebelumnya dan setelah intervensi [4].

Frekuensi lalu lintas kereta api yang melintasi Jalur Cirebon-Cikampek akan terus meningkat seiring dengan perkembangan industri perkeretaapian. Hal tersebut dapat mempengaruhi penurunan kualitas lintasan. Selain itu, seperti yang sudah diketahui pada bulan Februari 2018 lalu bahwa jalur kereta api di Daerah Operasi 3 Cirebon, Jawa Barat, tepatnya di jalur tengah antara Stasiun Ciledug-Ketanggungan mengarah ke Purwokerto dan Stasiun Tanjung-Losari arah Tegal, lumpuh total akibat banjir. Dengan adanya kondisi tersebut, maka dapat mengakibatkan suatu penurunan kualitas layanan maupun kualitas lintasan kereta api. Berdasarkan permasalahan di atas, terjadi penurunan kualitas lintasan maka perlu diadakannya suatu penelitian atau kajian terhadap penerapan TQI di Indonesia. Dalam penelitian ini, evaluasi kualitas jalan rel dihitung dengan menggunakan dua metode lainnya seperti $J$ Synthetic Coefficient dan Track Geometry Index (TGI Indian Railway) yang mempertimbangkan aspek geometri sebagai kriteria penurunan kualitas utama. Dengan diadakannya penelitian 
ini diharapkan dapat mengurangi permasalahan turunnya kualitas lintasan jalan rel dengan mengetahui nilai kualitas lintasan per segmen 200 meter untuk dasar penentuan kategori pemeliharaan.

\section{METODE}

Tahap awal penelitian ini yaitu tahap persiapan dengan melakukan pegambilan data di wilayah DAOP 3 Cirebon. Alasan pemilihan lokasi studi karena Cirebon salah satu kota yang dilewatu jalur ganda dari system perkeretaapian dimana jalur ganda ini merupakan jalur pertama yang dioperasikan di Pulau Jawa.

\section{A. Pengumpulan Data}

Dalam tahap ini dilakukan pengumpulan data sekunder yaitu data dari bacaan kereta ukur EM-120 yang didapatkan dari Direktorat Jendral Perkeretaapian. Data kereta ukur berisi data geometrik jalan rel CirebonCikampek tahun 2016 Analisis Data

Tahap analisis data diawali dengan menghitung standar deviasi dari tiap parameter per 200 meter, kemudian mengakumulasikan nilai standar deviasi dari keempat parameter yang menghasilkan nilai TQI. Melakukan perhitungan nilai kualitas indeks track dengan menggunakan metode Polandia J Synthetic Coefficient dan Track Geometry Index (TGI Indian Railway). Melakukan uji statistik untuk mengetahui perbedaan hasil nilai indeks kualitas track dari masing-masing metode yang digunakan. Analisa uji statistik yang digunakan yaitu dengan menggunakan tabulasi silang untuk mengetahui perbedaan pengukuran antara indeks TQI dan TGI. Selain itu, digunakan analisis regresi linier berganda untuk mengetahui parameter apa saja yang berpengaruh terhadap nilai TQI dan Koefisien Sintetik (J-Coefficient).

\section{B. Perhitungan Nilai TQI Indonesia}

Kualitas track didefinisikan sebagai nilai numerik yang mewakili kondisi relatif dari geometri permukaan track [4]. Dalam hal ini, indikator penilaian kualitas lintasan berdasarkan standar deviasi.

Standar deviasi (SD) memberikan kekasaran dari track. SD tidak hanya mudah untuk menghitung, menginterpretasikan, dan menggunakan tetapi juga memberikan gambaran umum tentang seluruh kualitas track yang dihitung [5]. Indeks Kualitas Track dihitung menggunakan standar deviasi dari nilai masing-masing segmen standar deviasi yaitu [6] :

$$
s=\sqrt{\frac{\Sigma \mathrm{xi}^{2}-\frac{\Sigma \mathrm{xi}^{2}}{n}}{n-1}}
$$

dengan :

$\mathrm{s} \quad=$ nilai standar deviasi

$\Sigma \mathrm{xi}^{2}=$ jumlah nilai $\mathrm{x}$ dikuadratkan

$\mathrm{n} \quad=$ jumlah data, maka

Nilai TQI diperoleh degan cara mencari nilai standar deviasi yang terjadi pada masing-masing segment. Satu segmen terdiri dari empat parameter yaitu angkatan, listringan, pertinggian dan lebar spur.

$\mathrm{TQI}=\mathrm{SD}$ ang $+\mathrm{SD}$ lis + SD per + SD lbr. spur

dengan :

SD ang = standar deviasi angkatan

SD lis = standar deviasi listringan

SD per $=$ standar deviasi pertinggian

SD lbr. spur = standar deviasi lebar spur
Standar nilai TQI yang digunakan PT. Kereta Api Indonesia (Persero) ditunjukkan pada Tabel 1.

\begin{tabular}{cccc}
\multicolumn{4}{c}{ Tabel 1. Standar nilai Track Quality Index (TQI) } \\
\hline Kategori & Total TQI & $\begin{array}{l}\text { Kecepatan } \\
(\mathrm{km} / \text { jam })\end{array}$ & $\begin{array}{c}\text { Jenis } \\
\text { Kategori }\end{array}$ \\
\hline I & TQI $\leq 20$ & $100-120$ & Baik Sekali \\
II & $20<$ TQI $\leq 35$ & $80-100$ & Baik \\
III & $35<$ TQI $\leq 50$ & $60-80$ & Sedang \\
IV & $>50$ & $<60$ & Jelek \\
\hline Sumber: Rulhendri, 2015 & &
\end{tabular}

\section{Perhitungan Nilai TGI Indian Railway}

Indian Railways telah mengembangkan formula untuk mewakili kualitas lintasan yang disebut TGI. TGI telah memberikan nilai yang berbeda untuk berbagai parameter geometri seperti yang ditunjukkan dalam rumus berikut [4]:

$\mathrm{TGI}=\frac{2 \mathrm{UI}+\mathrm{TI}+\mathrm{GI}+6 \mathrm{AI}}{10}$

dengan :

$\mathrm{UI}=$ Unevenness Index

$\mathrm{TI}=$ Twist Index

GI = Gauge Index

$\mathrm{AI}=$ Alignment Index

Untuk setiap parameter lintasan yang diukur, indeks dihitung dari relasinya :

GI, TI, AI, UI $=100 x e^{-\left(\frac{\text { SDmes-SD n }}{\text { SD maint-SD n }}\right)}(4)$

dimana :

$\mathrm{SD}_{\text {mes }}=$ standar deviasi parameter geometri terukur

$\mathrm{SD}_{\mathrm{n}} \quad=$ mewakili standar deviasi yang ditentukan untuk track baru

$\mathrm{SD}_{\text {maint }}=$ standar deviasi yang ditentukan untuk pemeliharaan

\begin{tabular}{|c|c|c|c|}
\hline Parameter & $\begin{array}{l}\text { SD } \\
\text { untuk } \\
\text { track } \\
\text { baru }\end{array}$ & $\begin{array}{l}\text { SD untuk } \\
\text { pemeliharaan } \\
\text { dengan maks. } \\
\text { kecepatan } \geq 105 \\
\mathrm{~km} / \text { jam }\end{array}$ & $\begin{array}{l}\text { SD untuk } \\
\text { pemeliharaan } \\
\text { dengan maks. } \\
\text { kecepatan }<105 \\
\text { km/jam }\end{array}$ \\
\hline Unevenness & 2,50 & 6,2 & 7,2 \\
\hline Twist & 1,75 & 3,8 & 4,2 \\
\hline Gauge & 1,00 & 3,6 & 3,6 \\
\hline Alignment & 1,5 & 3,0 & 3,0 \\
\hline
\end{tabular}

Sumber: Berawi, 2010

Tabel 3. Klasifikasi TGI untuk Pemeliharaan

\begin{tabular}{|c|c|c|}
\hline No & Nilai TGI & Persyaratan Pemeliharaan \\
\hline 1 & TGI $>80$ & $\begin{array}{l}\text { Tidak membutuhkan } \\
\text { pemeliharan (TMP) }\end{array}$ \\
\hline 2 & $50<\mathrm{TGI}<80$ & $\begin{array}{l}\text { Membutuhkan pemeliharaan dasar } \\
\text { (MPD) }\end{array}$ \\
\hline 3 & $36<$ TGI $<50$ & Pemeliharaan terencana (PT) \\
\hline 4 & TGI $<36$ & Perawatan mendesak (PM) \\
\hline
\end{tabular}

\section{Perhitungan Nilai J Synthetic Coefficient}

Koefisien sintetik digunakan sebagai indikator kualitas lintasan berdasarkan standar deviasi yang dikembangkan oleh Polish Railways. Empat parameter geometri lintasan dipertimbangkan dalam indeks ini yaitu ketidakteraturan vertikal, ketidakteraturan horizontal, puntiran (twist), dan lebar jalur. Persamaan untuk menghitung metode ini adalah :

$$
J=\frac{S_{z}+S_{y}+S_{w}+\left(0,5 \times S_{e}\right)}{3,5}
$$

dengan :

$\mathrm{Sz}=$ Standar deviasi dari ketidakteraturan vertikal

Sy $=$ Standar deviasi dari ketidakteraturan horizontal 
$\mathrm{Sw}=$ Standar deviasi dari twist

$\mathrm{Se}=$ Standar deviasi dari lebar jalur

Tabel 4. Batas kecepatan maksimal menurut J Synthetic Coefficient

\begin{tabular}{cccc}
\hline $\begin{array}{c}\text { Kecepatan } \\
(\mathrm{km} / \mathrm{jam})\end{array}$ & $\begin{array}{c}\text { J.Coeff } \\
(\mathrm{mm})\end{array}$ & $\begin{array}{c}\text { Kecepatan } \\
(\mathrm{km} / \mathrm{jam})\end{array}$ & $\begin{array}{c}\text { J.Coeff } \\
(\mathrm{mm})\end{array}$ \\
\hline 80 & 7 & 150 & 2,3 \\
90 & 6,2 & 160 & 2 \\
100 & 5,5 & 170 & 1,7 \\
110 & 4,9 & 180 & 1,6 \\
120 & 4 & 190 & 1,5 \\
130 & 3,5 & 200 & 1,4 \\
140 & 2,8 & $\left.220^{*}\right)$ & 1,1 \\
\hline
\end{tabular}

*Dihitung melalui ekstrapolasi

Sumber : Berawi, 2010

\section{E. Uji Statistik Tabulasi Silang Data}

Statistik deskriptif crosstab (tabulasi silang) termasuk dalam analisis deskripsi. Deskriptif crosstab menyajikan data dalam bentuk tabulasi, yang meliputi baris dan kolom. Analisis tabulasi silang (Crosstabs) adalah metode analisis yang paling sederhana tetapi memiliki daya menerangkan cukup kuat untuk menjelaskan hubungan antar variabel. Analisis ini menggunakan program SPSS. Untuk itu ada beberapa prinsip sederhana yang perlu diperhatikan dalam menyusun tabel silang agar hubungan antara variabel tampak dengan jelas. Untuk itu maka dalam analisis crosstabs digunakan analisis statistik yaitu Chi Kuadrat (Chi-Square) yang disimbolkan dengan $\chi 2$. Data yang digunakan adalah data frekuensi hasil pengukuran TQI dengan TGI dengan masing-masing kategori.

\section{F. Analisis Regresi Linier Berganda}

Analisis regresi linier digunakan untuk mengetahui hubungan mengetahui arah hubungan antara variabel independen dengan variabel dependen apakah masingmasing variabel independen berhubungan positif atau negatif dan untuk memprediksi nilai dari variabel dependen apabila nilai variabel independen mengalami kenaikan atau penurunan. Beberapa hal lain yang penting juga untuk dipahami dalam penggunaan analisis regresi linier ganda yaitu perlunya melakukan uji asumsi klasik atau uji persyaratan analisis regresi ganda sehingga persamaan garis regresi yang diperoleh benar-benar dapat digunakan untuk memprediksi variabel dependen. Dalam hal ini, data yang digunakan yaitu variabel independen adalah parameter pengukuran (angkatan, listringan, lebar spur, dan pertinggian) sedangkan variabel dependen adalah nilai TQI dan $J$ Synthetic Coefficient dengan menggunakan program bantu SPSS.

\section{G. Kesimpulan dan Saran}

Pengambilan kesimpulan berdasarkan hasil yang didapatkan pada tahap analisis. Penelitian ini diharapkan menjadi bahan referensi dalam melakukan kajian maupun penelitian lebih lanjut terkait penilaian kualitas lintasan dengan mempertimbangkan aspek lainnya selain aspek geometri.

\section{HASIL DAN PEMBAHASAN}

\section{A. Nilai TQI Indonesia}

Perhitungan nilai TQI dihasilkan dengan menjumlahkan keempat parameter, berikut contoh perhitungannya pada $\mathrm{km} \mathrm{51+200} \mathrm{adalah} \mathrm{sebagai} \mathrm{berikut} \mathrm{;}$

$\mathrm{TQI}=\mathrm{SD}$ angkatan $+\mathrm{SD}$ listringan $+\mathrm{SD}$ lebar spur $+\mathrm{SD}$ pertinggian

$$
\begin{aligned}
& =28,63+28,40+1,35+2,50 \\
& =60,88
\end{aligned}
$$

Dari hasil tersebut didapatkan nilai TQI sebesar 60,88 yang menunjukkan bahwa kualitas indeks rel masuk dalam kategori IV yaitu kategori jelek dimana total nilai TQI $>50$.

\section{B. Nilai TGI Indian Railway}

Untuk mendapatkan nilai TGI terlebih dahulu menghitung parameter lintasan yan diukur, berikut merupakan salah satu contoh perhitungan untuk parameter lebar spur pada $\mathrm{km} \mathrm{51+200} \mathrm{yaitu}$

$$
\begin{aligned}
& \text { GI }=100 x e^{-\left(\frac{\text { SDmes-SD n }}{\text { SDaint-SD n }}\right)} \\
& =100 x e^{-\left(\frac{\text { SDmes-SD n }}{\text { SD maint-SD n }}\right)} \\
& =100 x e^{-\left(\frac{1,35-1,00}{3,6-1,00}\right)} \\
& =87,30
\end{aligned}
$$

Dari perhitungan di atas didapatkan nilai dari parameter gauge yang mana perhitungan tersebut juga diterapkan untuk perhitungan parameter lainnnya, sehingga didapatkan nilai TGI sebagai berikut:

$$
\begin{aligned}
\mathrm{TGI} & =\frac{2 \mathrm{UI}+\mathrm{TI}+\mathrm{GI}+6 \mathrm{AI}}{10} \\
& =\frac{(2 \times 0,39)+73,49+87,3+(6 \times 0,00)}{10} \\
& =16,16
\end{aligned}
$$

Dari hasil perhitungan di atas didapatkan hasil TGI sebesar 16,16 yang menunjukkan bahwa nilai TGI masuk dalam persyaratan pemeliharaan perawatan yang mendesak dengan nilai TGI $<36$.

\section{Nilai J Synthetic Coefficient}

Sebagai contoh perhitungan penentuan indeks kualitas rel pada km 29 yaitu diketahui bahwa :

$$
\begin{aligned}
& \mathrm{Sz}=\mathrm{SD} \text { angkatan }=8,95 \\
& \mathrm{Sy}=\mathrm{SD} \text { listringan }=4,68 \\
& \mathrm{Sw}=\mathrm{SD} \text { pertinggian }=1,16 \\
& \mathrm{Se}=\mathrm{SD} \text { lebar spoor }=0.85 \\
& \text { Maka, nilai kualitas indeks rel } \\
& J=\frac{8,95+4,68+1,16+(0,5 \times 0,85)}{3,5}=4,35
\end{aligned}
$$

Dari hasil di atas didapatkan hasil dengan menggunakan metode Polandia J-Coefficient adalah 4,35 yang berarti bahwa kecepatan yang dihasilkan adalah 120 km/jam.

\section{Hasil Analisis Uji Statistik Tabulasi Silang Data}

Sebelum dilakukan analisis, perlu dilakukan uji chisquare untuk mengetahui apakah terdapat hubungan antara 2 variabel pengukruan tersebut secara statistik. Tabel 5 merupakan hasil pengujian chi-square antara TQI dan TGI.

\begin{tabular}{lrcc}
\multicolumn{4}{c}{ Tabel 5. Uji Chi-square Antara TQI dan TGI } \\
\hline \multicolumn{1}{c}{ Value } & Value & df & $\begin{array}{c}\text { Significance } \\
\text { (2-sided) }\end{array}$ \\
\hline Pearson Chi-Square & $92.991^{\mathrm{a}}$ & 6 & 0.000 \\
Likelihood Ratio & 83.458 & 6 & 0.000 \\
N of Valid Cases & 274 & & \\
\hline
\end{tabular}

Nilai signifikansi uji chi-square adalah 0.000 yang kurang dari derajat kesalahan penelitian sebesar 5\%, sehingga kesimpulannya adalah Tolak H0 atau terdapat hubungan antara hasil analisis TQI dan TGI. Setelah didapatkan hasil bahwa terdapat hubungan antar kedua variabel, maka selanjutnya dilakukan analisis tabulasi silang TQI dan TGI pada Tabel 6: 
Tabel 6. Tabulasi TQI dan TGI

\begin{tabular}{|c|c|c|c|c|c|c|}
\hline & & & \multicolumn{3}{|c|}{ TGI_kategori } & \multirow{2}{*}{ Total } \\
\hline & & & PM & PT & TMP & \\
\hline \multirow{8}{*}{$\begin{array}{c}\text { TQI } \\
\text { kategori }\end{array}$} & \multirow[b]{2}{*}{$\begin{array}{l}\text { Baik } \\
\text { Sekali }\end{array}$} & Count & 16 & 3 & 35 & 54 \\
\hline & & $\begin{array}{l}\% \text { of } \\
\text { Total }\end{array}$ & $5.8 \%$ & $1.1 \%$ & $12.8 \%$ & $19.7 \%$ \\
\hline & \multirow[b]{2}{*}{ Baik } & Count & 90 & 1 & 15 & 106 \\
\hline & & $\begin{array}{l}\% \text { of } \\
\text { Total }\end{array}$ & $32.8 \%$ & $0.4 \%$ & $5.5 \%$ & $38.7 \%$ \\
\hline & \multirow[b]{2}{*}{ Sedang } & Count & 51 & 0 & 3 & 54 \\
\hline & & $\begin{array}{l}\% \text { of } \\
\text { Total }\end{array}$ & $18.6 \%$ & $0.0 \%$ & $1.1 \%$ & $19.7 \%$ \\
\hline & \multirow[b]{2}{*}{ Jelek } & Count & 56 & 0 & 4 & 60 \\
\hline & & $\begin{array}{l}\% \text { of } \\
\text { Total }\end{array}$ & $20.4 \%$ & $0.0 \%$ & $1.5 \%$ & $21.9 \%$ \\
\hline \multirow{2}{*}{\multicolumn{2}{|c|}{ Total }} & Count & 213 & 4 & 57 & 274 \\
\hline & & $\begin{array}{l}\% \text { of } \\
\text { Total }\end{array}$ & $77.7 \%$ & $1.5 \%$ & $20.8 \%$ & $100.0 \%$ \\
\hline
\end{tabular}

Tabel tabulasi silang di atas menunjukkan TQI pada kondisi baik namun pada kategori TGI membutuhkan perawatan yang mendesak (PM) sebanyak 90 data atau sebesar 32,8\%. TQI pada kondisi baik sekali namun pada kategori TGI membutuhkan perawatan yang mendesak (PM) sebanyak 16 data atau sebesar 5,8\%. Dari data di atas didapatkan prosentase secara keseluruhan bahwa 77,7\% masuk dalam kategori PM (Perawatan Mendesak) sehingga kondisi menunjukkan adanya ketimpangan nilai pengukuran antara indeks TQI dan TGI.

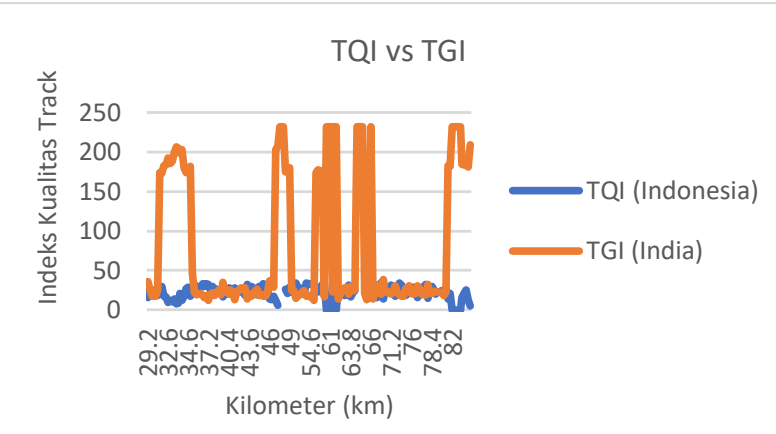

Gambar 1. Grafik TQI dengan TGI.

Dari grafik indeks di atas menunjukkan perbedaan nilai TQI dengan TGI. Grafik TQI menuju ke nilai 0, sedangkan grafik TGI memiliki pola fluktuatif dan menjauhi nilai 0 . Semakin grafik mendekati nilai 0 , maka kualitas rel semakin bagus. Artinya kualitas rel kereta sepanjang Cirebon-Cikampek dengan menggunakan metode Indonesia yang menghasilkan nilai TQI cenderung baik, akan tetapi jika menggunakan metode Indian Railway yang menghasilkan nilai TGI menunjukkan suatu indeks kualitas rel yang cenderung tinggi yang berarti lintasan rel tersebut dominan berada dalam kategori membutuhkan perawatan.

\section{E. Hasil Regresi Linier Berganda}

Sebelum menganalisis regresi linier berganda sebelumnya terlebih dahulu melakukan cek asumsi IIDN (Identik, Independen, Distribusi Normal). Pada cek asumsi IIDN (Identik, Independen, Distribusi Normal), asumsi Normalitas dilakukan dengan KolmogorovSmirnov. Asumsi independen dengan multikolinearitas data atau nilai VIF dimana nilai dari tiap parameter menunjukkan hasil kurang dari 10 yang artinya tidak terjadi multikolinieritas. Sedangkan pada asumsi identik dengan Correlate Residual Unstandardize yang menunjukkan nilai lebih dari alfa 5\% atau asumsi identik telah terpenuhi. Setelah itu, cek uji T diperlukan untuk menguji secara parsial masing-masing variabel dari parameter-parameter terkait sehingga dapat diketahui parameter apa saja yang berpengaruh. Untuk menentukan proporsi atau persentase total variasi dalam variabel terikat (variabel Y) yang diterangkan oleh variabel bebas (variabel $\mathrm{X}$ ) sehingga dapat diketahui seberapa besar pengaruh variabel $\mathrm{X}$ terhadap $\mathrm{Y}$ dengan menggunakan Koefisien Determinasi (Adjusted $R$ Square)

\begin{tabular}{lrrrr}
\multicolumn{2}{c}{ Tabel 7. Asumsi Normalitas dengan Kolmogorov-Smirnov } \\
\hline Model & \multicolumn{2}{c}{$\begin{array}{c}\text { Collinearity Statistic } \\
\text { VIF }\end{array}$} & \multicolumn{2}{c}{$\begin{array}{c}\text { Identik } \\
\text { Correlate Residual } \\
\text { Unstandardize }\end{array}$} \\
\hline TQI & J Synthetic & \multicolumn{2}{c}{ TQI J Synthetic } \\
(Constant) & \multicolumn{3}{c}{ (Sig (2-tailed) } \\
Angkatan & 1,080 & 1,080 & 1,000 & 1,000 \\
Listringan & 1,434 & 1,434 & 1,000 & 1,000 \\
Lebar Spur & 1,021 & 1,021 & 1,000 & 1,000 \\
Pertinggian & 1,343 & 1,343 & 1,000 & 1,000 \\
\hline
\end{tabular}

Dari hasil asumsi normalitas di atas didapatkan bahwa nilai VIF $<10$ sehingga tidak terjadi multikolinieritas dan asumsi identik $>5 \%$ maka asumsi identik telah terpenuhi

\begin{tabular}{|c|c|c|c|c|}
\hline \multicolumn{5}{|c|}{ Tabel 8. Hasil Pengujian Uji T } \\
\hline \multirow[t]{2}{*}{ Model } & \multicolumn{2}{|c|}{$\begin{array}{l}\text { Unstandardized } \\
\text { Coefficient } \\
\text { (B) }\end{array}$} & \multicolumn{2}{|c|}{ Sig. } \\
\hline & TQI & J Synthetic & TQI & J Synthetic \\
\hline (Constant) & 0,000 & 0,000 & & \\
\hline Angkatan & 1,000 & 286 & 000 & 000 \\
\hline Listringan & 1,000 & 143 & 000 & 000 \\
\hline Lebar Spur & 1,000 & 286 & 000 & 000 \\
\hline Pertinggian & 1,000 & 286 & 000 & ,000 \\
\hline
\end{tabular}

Dari tabel di atas didapatkan hasil nilai p-value untuk kedua metode yaitu TQI dan J Synthetic yaitu angkatan (0.000), listringan (0.000), lebar spur (0.000) dan pertinggian (0.000) yang kurang dari 5\%, sehingga dapat disimpulkan bahwa keempat parameter memiliki pengaruh yang signifikan terhadap index TQI dan J Synthetic. Parameter yang paling besar pengaruhnya dapat dilihat dari besar nilai B Unstandardized Coefficients dimana untuk TQI hasilnya menunjukkan bahwa angkatan, listringan, lebar spur, dan pertinggian adalah 1.000, artinya semua parameter memiliki sumbangan yang sama terhadap pengaruh TQI. Sedangkan untuk J Synthetic hasilnya menunjukkan bahwa angkatan, listringan, dan pertinggian menghasilkan nilai 0,286 serta lebar spur dengan nilai 0,143, artinya parameter angkatan, listringan, dan pertinggian memiliki sumbangan terbesar terhadap pengaruh J-Coefficient.

Tabel 9. Hasil Koefisien Determinasi (Adjusted R Square)

\begin{tabular}{|c|c|c|c|}
\hline \multicolumn{4}{|c|}{ TQI } \\
\hline \multicolumn{4}{|c|}{ Model Summary ${ }^{\mathrm{b}}$} \\
\hline $\mathrm{R}$ & R Square & $\begin{array}{l}\text { Adjusted R } \\
\text { Square }\end{array}$ & $\begin{array}{c}\text { Std. Error of the } \\
\text { Estimate }\end{array}$ \\
\hline 1,000 & $1,000^{\mathrm{a}}$ & 1,000 &, 00578 \\
\hline \multicolumn{4}{|c|}{$\begin{array}{l}\text { a. Predictors : angkatan, listringan, lebar spur, pertinggian } \\
\text { b. Dependent Variabel : TQI }\end{array}$} \\
\hline \multicolumn{4}{|c|}{ J Synthetic } \\
\hline \multicolumn{4}{|c|}{ Model Summary ${ }^{\mathrm{b}}$} \\
\hline $\mathrm{R}$ & R Square & $\begin{array}{l}\text { Adjusted R } \\
\text { Square }\end{array}$ & $\begin{array}{l}\text { Std. Error of the } \\
\text { Estimate }\end{array}$ \\
\hline 1,000 & $1,000^{\mathrm{a}}$ & 1,000 & ,00578 \\
\hline \multicolumn{4}{|c|}{$\begin{array}{l}\text { Predictors : angkatan, listringan, lebar spur, pertinggian } \\
\text { Dependent Variabel : J Synthetic }\end{array}$} \\
\hline
\end{tabular}


Tabel 9 merupakan nilai kesesuaian model, apakah pemodelan yang dilakukan sudah tepat atau kurang tepat. Hasilnya menunjukkan bahwa nilai R-Square sebesar 1,000 yang artinya keempat parameter (angkatan, listringan, lebar spur, pertinggian) mampu menjelaskan index TQI dan J Synthetic sebesar 100\%, sedangkan sisanya yaitu $0 \%$ dijelaskan oleh parameter lain di luar model.

\section{KESIMPULAN}

Beberapa kesimpulan yang didapat dari beberapa hasil yang telah dibuat pada penelitian ini adalah sebagai berikut.

1. Hasil analisis dari uji statistik tabulasi silang menyatakan bahwa nilai TQI jika diintepretasikan dengan nilai kategori TGI menyatakan bahwa 77,7\% data masuk dalam kategori perawatan mendesak. Dari hasil tersebut menunjukkan adanya ketimpangan nilai pengukuran antara nilai TQI dengan TGI.

2. Berdasarkan grafik antara nilai TQI dengan TGI menunjukkan adanya perbedaan pola grafik. Grafik TGI menunjukkan pola fluktuatif dibandingkan dengan TQI yang memiliki pola grafik stabil. Sehingga dapat diartikan bahwa nilai TGI menghasilkan nilai indeks kualitas lintasan yang cenderung tinggi dan dominan masuk dalam kategori membutuhkan perawatan.

3. Hasil analisis regresi linier berganda menunjukkan bahwa dalam pengujian Uji $\mathrm{T}$ keempat parameter memiliki pengaruh yang signifikan terhadap TQI dan J Synthetic. Dalam hal ini, semua parameter memiliki sumbangan yang sama terhadap pengaruh TQI dengan nilai B sebesar 1,000. Sedangkan J Synthetic menunjukkan bahwa parameter angkatan, listringan, dan pertinggian memiliki sumbangan terbesar terhadap pengaruh J-Coefficient dengan nilai B sebesar 0,286. Pengaruh parameter angkatan, listringan, lebar spur dan pertinggian memiliki pengaruh positif, artinya apabila parameter tersebut bertambah 1 satuan, maka nilai J- Coefficient akan bertambah 1 satuan yang berarti kecepatan laju kereta semakin rendah.

4. Berdasarkan tabel output SPSS "Model Summary", diketahui nilai koefisien determinasi atau R Square adalah sebesar 1,000. Besarnya angka koefisien determinasi (R Square) adalah 1,000 atau sama dengan $100 \%$. Angka tersebut mengandung arti bahwa keempat parameter (angkatan, listringan, lebar spur, dan pertinggian) secara simultan (bersama-sama) berpengaruh terhadap variabel TQI dan J Synthetic. Sedangkan sisanya $0 \%$ dipengaruhi oleh parameter lain di luar model.

\section{DAFTAR PUSTAKA}

[1] P. Xu, R. Liu, F. Wang, Q. Sun, and H. H. Teng, "International Journal of Computational Intelligence A Novel Description Method for Track Irregularity Evolution," no. December, 2017.

[2] P. Xu, R. Liu, Q. Sun, and F. Wang, "A Novel Short-Range Prediction Model for Railway Track Irregularity," Discret. Dyn. Nat. Soc., vol. 2012, no. December 2012, pp. 1-12, 2012.

[3] H. Askarinejad, "Influences of Track Structure, Geometry and Traffic Parameters on Railway Deterioration," no. December 2007, 2017.

[4] A. R. B. Berawi, R. Delgado, R. Calçada, and C. Vale, "Evaluating track geometrical quality through different methodologies," Int. J. Technol., vol. 1, no. 1, pp. 38-47, 2010.

[5] Rizwan, An empirical rail track degradation model based on predictive analysis of rail profile and track geometry. 2010.

[6] W. Kurniawan, "Tinjauan Volume Pemeliharaan Tahunan Jalan Rel Berdasarkan Hasil Track Quality Index (TQI) (Studi kasus: Lintas Manggarai - Bogor)," vol. 4, no. 1067 mm, pp. $1-17,2015$. 